\title{
The Mismatch between Non-native English as a Foreign Language (EFL) Teachers' Grammar Beliefs and Classroom Practices
}

\author{
Rabia Hos \\ Department of English Language Teaching, Zirve University, Gaziantep, Turkey \\ Mustafa Kekec \\ Department of English Language Teaching, Zirve University, Gaziantep, Turkey
}

\begin{abstract}
Teachers' beliefs affect their classroom practices, whether these beliefs are implicit or explicit (Williams \& Burden, 1997). However, there may be discrepancies between what teachers believe and practice. The purpose of this study was to investigate the mismatches between language instructors' beliefs and practices regarding grammar teaching. The participants were non-native instructors of English as a foreign language (EFL). A 12-item qualitative questionnaire was used for the data collection. Classroom observations were also conducted to observe how grammar was taught in the classroom. The data were analyzed in abductive and iterative manner (Dörnyei, 2007). There were three main findings to the study: 1) Many of the teachers believed that communicative language teaching method (CLT) would be the best method to teach grammar. 2) The teachers who favored CLT did not make use of it in their classrooms and many used grammar translation method (GTM). 3) Finally, the washback effect (Taylor, 2005) widely influenced teachers' way of grammar teaching. This study makes a contribution to the TEFL field by revealing the mismatches between teachers' beliefs on what would be the most beneficial for student learning when teaching grammar and the classroom practice realities.
\end{abstract}

Index Terms - English as a foreign language, teacher beliefs, classroom practices, non-native EFL teachers

\section{INTRODUCTION}

Teaching of grammar is an essential part of language pedagogy, which is also a controversial issue. With such controversies, language teachers also have distinctive views on grammar teaching. Joyce \& Burns (1999) suggested that teacher' beliefs of what grammar is influences the way they teach grammar in the classroom. Teachers' decisions are mostly dependent upon their beliefs, attitudes, and theories that they have acquired (Burns, 1996). These are part of what is considered teacher cognition (Borg, 2003). Borg (1999) describes teacher cognitions as consisting of "a set of personally defined practically oriented understanding of teaching and learning which exert significant influence on instructional decisions" (p. 22).

The study of teachers' beliefs has been a major area of study in language teaching. One of the strands in this area is looking at the relationship between teachers' beliefs and their actual practices and how they overlap or not (KaravasDoukas, 1995). In this article, we describe the inconsistencies or mismatches between teachers' cognition and their classroom practices in teaching grammar.

\section{LITERATURE REVIEW}

\section{A. Teachers' Beliefs}

Borg (2003) states: "teachers are active, thinking decision-makers who make instructional choices by drawing on complex practically-oriented, personalized, and context-sensitive networks of knowledge, thoughts, and beliefs" (p. 81). According to Freeman (2002), mental lives of teachers have critical significance in shaping effective teaching and learning process. Therefore, it is crucial to find out teachers' beliefs as they can be reflected in the classrooms. Kagan (1992) defines teachers' beliefs as 'tacit, often unconsciously held assumptions about students, classrooms and the academic material to be taught" (p. 65). However, Johnson (1994) maintained that teacher beliefs are not easy to delineate and study since they are not directly measurable. Pajares also (1992) stated that it is not easy to empirically investigate beliefs.

Johnson (1994, p. 439) outlines three assumptions regarding teachers' beliefs: (1) Teachers' beliefs affect perception and judgment. (2) Teachers' beliefs are reflected in classroom practices. (3) There is a need to understand teachers' beliefs with a view to improving teaching practices and teacher education programs.

Richards \& Lockhart (1994) expressed that beliefs are built up over time. They argue that beliefs include both subjective and objective dimensions, and they play roles as bases for teachers' decisions and classroom practices. The 
composition of teachers' beliefs is neither uniform nor simple, and beliefs appear to be interwoven and have many facets (Mohamed, 2006). Teachers' beliefs about what learning is will affect everything they do in the classroom, whether these beliefs are implicit or explicit (Williams \& Burden, 1997). The National Institute of Education in the United States realized in 1975 the importance of such field of research by stating that what teachers think and believe influence what they do in the classroom. Fenstermacher (1979) also predicted that teachers' beliefs would be a prominent research field nearly three decades ago. However, given the available research studies about teachers' beliefs and their classroom practices in Turkey, it is of utmost importance to conduct such a study with a view to understand the possible mismatches between beliefs and practices.

\section{B. Teachers' Cognition and Grammar Teaching}

Teacher cognition is defined as "what teachers know, believe, and think" (Borg, 2003, p. 81). Borg (2003) characterizes the importance of social and instructional contexts in the study of teacher cognition. Looking at teacher cognition provides an insight into how teachers make instructional decisions. Among many of the teacher cognition studies, teachers' beliefs about grammar teaching have been a crucial domain of research (Borg, 2006). Considering the important role of grammar in second language acquisition, teachers' beliefs and practices about grammar cannot be ignored. As Borg and Burns (2008) expressed: "No area of second and foreign (L2) language learning has been the subject of as much empirical and practical interest as grammar teaching" (p.1).

Major questions that arise around the issue of grammar teaching are whether grammar should be taught deductively or inductively, whether to teach it as a separate skill or integrated or whether the knowledge of grammar supports language learning (Nishimuro \& Borg, 2013). It has been found that instructional practices that teachers apply when teaching grammar may be influenced by different cognitive and contextual factors. Some of the variables that may effect teachers' beliefs are work environment, personal characteristics of teachers such as age, gender and educational background (Moini, 2009).

Research studies in different settings have been conducted to reveal what teachers' beliefs and practices are regarding grammar teaching. Richards, Galloo, and Renandya (2001) investigated the beliefs of English teachers about grammar. They found that communicative approach and direct grammar teaching were favored by the teachers and that the students were aware of the value of grammar and expected it to be taught. Borg (2001) found that both the teachers' knowledge of grammar as well as how confident they are about that knowledge influenced their teaching. Andrews (2007) found that teachers' knowledge about grammar makes a difference in the instructional decisions they make when teaching it. Borg and Burns (2008) found in their sample of international teachers that grammar should not be taught separately.

Schulz's cross-cultural study (2001) found that Colombian teachers and US teachers differed in their beliefs regarding the effectiveness of explicit grammar teaching and corrective feedback. Schulz (2001) concludes that the differences in beliefs can be due to the teachers' previous learning experiences. Mohamed's (2006) study revealed that the dominant belief of the 197 teachers who participated in the study was that grammar instruction is a crucial component of the language classroom and grammar was primarily seen as rules of the language. Teachers were unfamiliar with inductive approaches to grammar instruction and they wanted their students to produce error-free sentences. Another study by Eisenstein-Ebsworth and Schweers (1997) found that Puerto Rican teachers were in favor of teaching grammar explicitly.

Chia (2003) examined the beliefs of primary teacher in Singapore and revealed that formal instruction of grammar was favored by teachers. The similar findings were drawn out from Burgess and Etherington's (2002) study. Overall, the participants stated that formal teaching contributes to the learners' proficiency. Altunbasak (2010) also found that the majority of the participant teachers believed that formal grammar teaching has a place in language learning.

These findings may be the general consensus among language teachers, and yet their approach to grammar is shaped not only by their beliefs about language learning, but also by their students and contextual circumstances (Farrell \& Lim, 2005). In looking at these studies, although it is important to know the teachers' beliefs about how grammar should be taught (Basturkmen, Loewen, \& Ellis, 2004), it is of utmost importance to know how these beliefs are practiced in classroom settings. (Pahissa \& Tragant, 2009).

\section{The Match/Mismatch between Teachers' Beliefs and Practices}

Teachers' cognitions and their actual practices in the classroom are two main domains of teaching process (Clark \& Peterson, 1986). However, teachers may not apply what they believe in the classroom. As Fang (1996) noted, mismatches between beliefs and practices can arise from different psychological, social and environmental factors that prevent teachers from applying their own personal beliefs in their instructional decision-making. Another explanation for such mismatches may be what Schulz (2001) defines as the "perturbing differences" (p.348) which refers to learners and teachers' different views regarding how second languages should be learned.

Johnson' study (1994) indicated that teachers adopted a teacher-centered approach to "maintain the flow of instruction and to retain authority in the classroom" (p. 449) although they favored student-centered approach. Richards (1994) stated that "the need to follow a prescribed curriculum, lack of suitable resources, and the students' ability levels" (p. 387) can prevent teachers from acting based on their beliefs.

Basturkmen, Loewen, and Ellis (2004) revealed that teachers' espoused beliefs are not necessarily reflected in 
classrooms, especially as they respond to unanticipated events in a lesson. Baleghizadeh and Farshchi (2012) found that formal instruction, the use of grammatical terminology, and explicit grammar teaching are valued by EFL teachers although the majority of the respondents believed in inductive, implicit, problem solving activities, and presentation through authentic texts. This finding reveals the discrepancy between what they believe theoretically and what they do in the classroom due to some factors. In their study, Phipps and Borg (2009) investigated mismatches in the grammar teaching beliefs and practices of the teachers. They found that there were some cases that teachers practiced contrary to their beliefs. The factors that caused teachers to practice in ways that were not congruent with their beliefs were mainly learner expectations and preferences, and classroom management concerns. Altunbasak (2010) revealed some mismatches between teachers' espoused beliefs for grammar activities and their actual practices in teaching.

\section{SigNIFICANCE OF THE STUDY}

English is learnt by more non-native speakers as a second language than native speakers (Canagarajah, 2005). As there are also more EFL learners than ESL learners (Andrews, 2007), the research studies about teachers' beliefs and practices in the literature are not accurate representative of a variety of language teaching settings around the world. Besides, the majority of the research studies on teachers' beliefs focused only on self-reports through questionnaires and interviews, with only a few studies examining if teachers put into practice their beliefs in the classroom (Mohamed, 2006). Given the continuing prominence of grammar teaching in the field of language acquisition, qualitative research in this context is essential in providing a deeper understanding of what teachers' beliefs are and how they are mediated in classroom contexts. The study we report here responds to this need. This study aims to reveal both self-reported teachers' beliefs and their practices in grammar teaching in the classroom contexts.

\section{METHODOLOGY}

Informed by the literature noted above, the following research questions were asked:

1) What are the teachers' beliefs regarding grammar teaching in an English preparatory school at a university?

2) What are the teachers' grammar teaching practices in grammar classes?

3) What are the mismatches between teachers' espoused beliefs and actual practices regarding grammar teaching?

\section{A. Setting}

The context for this study was a private university's English preparatory program, where every student entering the university had to spend a semester to a year depending on his or her proficiency. The courses were taught as separate skills and there were four levels and four skills that were taught.

\section{B. Participants}

The participants for this study were sixty Turkish instructors who teach EFL in the preparation program at a School of Foreign Languages. Out of the total 110 instructors sixty decided to participate in this study. The participants were chosen based on convenience and access. Participants generally differed in terms of the universities they graduated, and their teaching experiences. Their majors ranged from English Language Teaching to Translation and English Language and Literature.

\section{Data Collection}

This study employed a qualitative methodology, which was appropriate given our goal of understanding beliefs and practices of teachers in depth. The researchers first distributed an open-ended questionnaire in person to the participants, and they were given a day to either complete the questionnaire after work hours or at home. The response rate was good as sixty out of the 110 instructors returned their questionnaires. In order to complement the responses given on the questionnaire, the researchers also conducted classroom observations in those teachers' grammar skill classes. Out of the ten grammar classes, seven were observed. Field notes, audio-recordings of the class sessions were also taken.

\section{The Instrument}

The instrument that was used for collecting the data included 12 open-ended questions. The questionnaire was developed by the researchers on the basis of the research questions and existing literature on teachers' beliefs about grammar. In order to assess the validity and reliability of the instrument, the questionnaire was piloted with twenty participants and revisions were made based on the responses. Teachers' beliefs were divided into different categories: a) definition of grammar b) importance of grammar c) approach to teaching grammar d) feedback and error correction e) practices used in teaching grammar.

\section{E. Data Analysis}

Data were analyzed by the researchers in an iterative manner (Dörnyei, 2007). Calderhead (1996) proposed five domains of teachers' beliefs that can be analyzed: beliefs about learners and learning, beliefs about teaching, beliefs about subject, beliefs about self and the teaching role, and beliefs about learning to teach. The first four categories were used to analyze the findings. As Ellis (2006) suggested from his study of grammar teaching, we also created sub- 
categories for the analyses of teachers' beliefs and practices such as inductive/deductive teaching, the use of native/target language, method of teaching, and error correction.

\section{FINDINGS}

The analyses of the teachers' beliefs and their actual practices indicated that the beliefs and practices were generally aligned but there was a mismatch between what they believed and what they practiced. In the section presented below, we discuss the various themes that arose as a result of our analyses.

\section{A. Beliefs about Language Learners}

The participant teachers tend to think that language learners value grammar and they think that it needs to be taught in general. According to the teachers, one of the major reasons is that learners are educated in a system that values grammar. As learners' language proficiency is measured with tests that include grammar questions, teachers think that students feel obliged to learn grammar in order to prove their language proficiency. It was also stated that the value given to grammar by teachers influence students' views on grammar. One participant teacher (T8) emphasizes the impact of teachers' approach to grammar on students by stating: "The more importance we give to grammar, the more attention students will pay to it".

Some participants stated that learners perceive grammar as an amalgamation of rules that need to be learnt. Therefore, they expect to be given ready-made rules by the teacher. One of the participants (T14) expressed that students are highly motivated to learn grammar, as they think that knowing grammar will assist them to pass the exams. She stated: "Students are extrinsically motivated because grammar part is \% 40 percent of the total exam." On the other hand, few teachers believed that their students think that grammar is unnecessary and emphasis on grammar prevents them from using the language in communicative ways.

\section{B. Teachers' Beliefs about Themselves and Their Roles}

\section{a. Teachers' Beliefs about the Place of Grammar in Language Teaching}

Nearly half of the participants believed that grammar is crucial in language learning and teaching. One of the participants (T4) stated: "It is very important because without grammar it could be impossible to construct the building". Others consider grammar as not a must, but a tool in language learning. A participant gives references from Krashen's acquisition hypothesis (1982) to deemphasize the role of grammar. One participant (T11) maintained that 'zero grammar' approach should be adopted and the focus should be on productive skills.

\section{b. Error Correction}

Most of the participants believed that there is no need to correct the students if they manage to convey their message across despite grammatical mistakes in their speech. The accuracy should be subordinated to fluency, and the first objective should be to convey message according to the majority, especially at early levels. One teacher (T1) made a difference between errors and mistakes. She stated: Errors, rather than mistakes should be corrected. Some participants emphasize the significance of the mistakes as they show the progress in students' interlanguage. However, the participants added that the frequent mistakes should be corrected in order to prevent fossilization process.

On the other hand, the classroom observations revealed that teachers generally corrected students' grammatical mistakes although students generally managed to convey their message across. Some of the teachers even corrected mistakes regarding grammar topics that students had not yet studied. For instance, a student formed an incorrect sentence in a passive structure and the teacher $(\mathrm{O} 1)$ immediately corrected the mistake although they had not yet studied the passive. It was also observed that some students were afraid of making mistakes and their affective filter was high, as their mistakes were to be corrected by the teacher.

\section{Teachers' Beliefs about Language Teaching}

\section{a. Beliefs towards Teaching Methodology}

The findings indicate that almost all participants stated that they were taught English through mostly GTM. However, teachers do not generally adopt language-teaching methods with which they were taught. The majority of the participants stated that they mainly make use of Communicative Language Teaching (CLT) in their grammar lessons. Few participant teachers believed in the effectiveness of Grammar Translation Method (GTM). A few participants were in favor of using Eclectic Approach to teaching grammar. They thought that different techniques from a variety of the methods should be benefitted depending on the teaching context. One of the participant teachers (T5) expressed: "I use a variety of methods ranging from GT to CLT by considering the level of the students, grammar items being taught, and the objectives of the course."

It has been drawn out from the classroom observations that although the majority of the participants maintained that they make use of CLT in the classroom, the observed methodology by the researchers was mainly GTM. There were mechanical drills and exercises reinforced with translations to students' native language. This was a clear mismatch from the teachers' reported beliefs and their actual classroom practices when teaching grammar.

The participants were also asked to list some techniques that they could use to teach grammar. The majority of them stated that communicative activities that engage students should be used in the grammar lessons. However, the 
classroom observations revealed that the most frequently used techniques were teacher-led question-and-answer and translation from the target language to L1 rather than communicative activities.

\section{b. Deductive vs. Inductive Instruction}

The majority of the participants believed that both inductive and deductive instruction should be used in grammar classes depending on the circumstances. They stated that some learners benefit from inferring the rules while others learn better if they are provided with presentation of the rules and then examples. However, the classroom observations revealed that the majority of the participants taught grammar only deductively as opposed to their espoused beliefs of integrating both deductive and inductive instruction into the lesson. Few teachers were observed to be using both deductive and inductive instruction in their grammar lessons.

\section{c. The use of native language}

The majority of the participants believed in the effectiveness of benefitting from students' native language (L1) at early levels, but they added that the use of L1 should be reduced at advanced levels. Some participants thought that use of L1 saves time, increases students' motivation, and reduces the ambiguity.

The classroom observations that were conducted at upper-intermediate and advanced levels indicated that the majority of the language teachers mostly used English and sometimes benefitted from L1 to clarify the students' misunderstanding. For example, a participant teacher (O2) compared L1 and L2 in students' native language to assist students comprehend the structure. On the other hand, a teacher used just students' L1 when teaching the target language although students were advanced. The interesting point was that the most active participation to the lesson by students were in this class.

\section{d. The contextual teaching of grammar}

The participants expressed that grammar should be taught contextually rather than in a mechanical way as a separate skill. Most of them were in favor of teaching grammar contextually with the integration of the grammar with other skills of the language. However, the classroom observations showed that the lessons were mostly based on a mechanical presentation of the grammar with a focus on the drill and exercises.

\section{e. The factors that teachers consider in grammar teaching}

The participants stated that the context, students' profiles, course objectives, curriculum, content, and available materials are among the determining factors that affect their grammar teaching process. They expressed that they plan their lessons by considering these crucial factors. The most frequently referred factor was students. The participants thought that students' needs, interests, and motives should be carefully determined in order to provide an effective lesson. One of the participants (T3) wrote: I consider students' background knowledge, their interests, and even their moods in grammar teaching. However, during the classroom observations there did not seem to be a differentiation based on students' individual needs.

\section{DISCUSSION}

Given the findings of the study, this study reveals that the beliefs of non-native language teachers were not always aligned with their actual practices in teaching grammar.

The majority of the participant teachers are of the opinion that their learners are motivated to learn grammar. One reason why teachers think that their students value grammar may be 'washback effect' that can be defined as the influence of tests on teaching and learning process (Alderson \& Wall, 1993). The participant teachers stated that as exams that measure students' language proficiency include grammar questions, students believe that learning grammar will help them to pass the exams and be proficient in the target language. On the other hand, some teachers expressed that they believe that their students are not motivated to learn grammar. They think that their students demand that the lessons be focused on productive skills such as speaking rather than grammar, as speaking the target language fluently will assist them to increase the likelihood of their promotion in business life. These students that consider English as a tool to achieve their objectives have mostly instrumental motivation (Gardner \& Lambert, 1982).

Error correction is a controversial issue as there is no conclusive result in the literature (Russell \& Spada, 2006). As Krashen (1982) stated, a low affective filter is necessary to acquire a language. Therefore, creating a friendly atmosphere in the classroom is important to provide effective error correction feedbacks. Most of the participants in the study are of the opinion that focusing on the grammatical mistakes in a communicative activity can demotivate students.

Teachers should be selective in error correction, as errors indicate the gaps in a learner's interlanguage while mistakes show lapses in performance (Ellis, 2006). However, classroom observations revealed that their beliefs about corrective feedback did not match with their classroom practices. Teachers in the classroom corrected almost every mistake, both minor and major ones. 'Observer effect', the influence of the observation on the phenomenon being observed (Cresswell, 2009), can be a partial explanation of the mismatch between beliefs and practices. The participant teachers may have corrected all the mistakes in order not to give the researcher the impression of lack of content knowledge. In a study by Ngo and Farrell (2003), although teachers believed in the effectiveness of elicitation technique, they used explicit correction rather than elicitation as the latter demands time and is not practical according to teachers.

The place of grammar in language education is open to debate. Long and Robinson (1998) outlines three options in language teaching (i.e. focus on forms, focus on form, and focus on meaning). The option, 'focus on forms', refers to 
'accumulated entities' view of Rutherford (1987, p.4), which emphasizes the discrete items of language. The interface hypothesis by Ellis (2006) suggests that explicit knowledge can turn into implicit knowledge if leaners find opportunities to practice the target language in communicative activities. Therefore, participants who teach grammar explicitly should also give importance to communicative practices. A teacher that appraises the grammar as a critical component is likely to give much importance to grammar teaching and adopt focus on forms options in language teaching. Given the findings of the study, half of the participants are in favor of 'focus on forms' options and they consider grammar as a crucial component of language that needs to be taught explicitly.

Some participants are of the opinion that grammar is a tool to be proficient in the target language. These participants may adopt focus-on-form option to language teaching. 'Focus on form', is defined by Long (1991, p. 45) as a teaching option that "overtly draws students" attention to linguistic elements as they arise incidentally in lessons whose overriding focus is on meaning or communication".

A participant who was in favor of 'zero grammar' is likely to prioritize 'focus on meaning' in language teaching (Ellis, 2006). 'Focus on meaning' is called 'non-interventionist' by Long and Robinson (1998, p.18). It does not emphasize grammar teaching and allows learners to naturally build their own interlanguage (Andrews, 2007).

The majority of the participants stated that they mostly make use of CLT to teach grammar while some use GTM and Eclectic Approach. The findings indicate that although nearly all participants were taught English through GTM, they stated that CLT is the most frequently used method by them. It can be inferred that previous learning experiences can affect a teacher's way of teaching. Richards and Lockhart (1996) also found that teachers' experience as language learners were among the main sources that shaped teachers' beliefs. However, previous experiences are not the only determining factors that shape how a teacher delivers the lesson. Regarding classroom observations, the classroom observations revealed that the teachers mainly taught English through GTM as opposed to the their statements that they use CLT in their grammar lessons, which is another mismatch between cognition and practice.

The participant teachers stated that they integrate both inductive and deductive teaching into their grammar lessons, but the observations showed that the grammar was mainly taught deductively as opposed to their espoused beliefs of integrating both deductive and inductive instruction into the lesson. Nagata (1997) states that the level of complexity of the rules, the degree of recognizability of the rules, and the clarity of the rules should be considered by teachers when teaching deductively or inductively.

The teachers in the study believe in the effectiveness of using students' L1 when teaching grammar. These views are in parallel with the findings of Atkinson (1987), Schweers (1999), and Tang (2002) who found that judicious use of L1 is a valuable resource. However, the participant teachers add that the amount of L1 should be reduced as learners move into the next language levels. They state that using L1 saves time, increases motivation, and reduces the ambiguities. The observed teachers generally reflected their espoused beliefs into the classroom. They sometimes benefitted from L1 in order to maintain the flow of the lesson. On the other hand, one teacher mostly taught grammar in students' native language, and the most active participation and the most motivated learners were observed to be in this class. This may be because students did not face any ambiguities that can challenge them to understand the lesson.

The majority of the participant teachers were in favor of teaching grammar in a context rather than in isolation. Nunan (1989) states that language learners should be provided with the opportunity of comprehending relationships between the form, meaning, and use. He also adds that grammar and context are so connected that suitable grammatical choices can only be achieved in relation to context. Therefore, grammar should be presented by integrating it into an appropriate context. However, the classroom observations indicated that grammar was generally taught in isolation rather than contextually. This may be due to students' expectations, time limit and catching up with the curriculum, or washback effect. The findings of this study are parallel with the study of Phipps and Borg (2009). They also found that expository approach to grammar was common in the classrooms although teachers' stated beliefs were that grammar should be presented in a context.

In this study, it was found that the mismatches were generally due to some major reasons such as students' profiles, course objectives, curriculum, content, and available materials, and setting. In a similar study, Phipps and Borg (2009) suggested that the factors that caused teachers to practice in ways that were not congruent with their beliefs were mainly learner expectations and preferences, and classroom management concerns.

\section{IMPLICATIONS}

According to the findings of this study, some general implications can be offered for a better teaching and learning process. Johnson (1994) suggests that teachers' beliefs should be understood in order to make teaching practices and teacher training services better. As Phipps and Borg (2009) also stated, investigating the underlying inconsistencies between teachers' beliefs and practices can assist teacher trainers to understand effective teaching. Therefore, beliefs should be deeply investigated, as they are among the major factors that influence education process. Borg (2001) found out that self-perceptions of teachers' knowledge about language (KAL) had an impact on their pedagogical decisions. Therefore, teachers should be provided with in-service education in order to inform them of the latest trends in language teaching and to reactivate their background pedagogic content knowledge. In addition, due to washback effect, students' oral language proficiency should be also measured and evaluated in grading students. As the examinations and testing influence the education process, the grading criteria should be changed in parallel with the linguistic objectives. Both 
pre-service and in-service teachers should make self-observations and reflect on their practices in order to raise awareness regarding their cognitions.

\section{CONCLUSION}

The current study makes a contribution to the field as its methodology offers a more-in-depth understanding of what the reported beliefs are and the actual practices that may or may not match with the beliefs. The studies that include more qualitative methods on exploring teachers' beliefs and actual practices offer an understanding of the complex relationship between these phenomena. While this understanding is helpful for researchers, it is also a way that instructors themselves are encouraged to explore their beliefs and reconsider their current practices.

Considering that this study is one of the few studies that offer a qualitative understanding of teachers' beliefs and actual practices, it also has some limitations that should be recognized. First, this study did not involve participants from different contexts and the findings may not be a representative of other contexts. It is important to further this study involving other schools both state and private in Turkey. Second, this study was limited in observation of actual practices and it may be helpful to consider a longitudinal observation of classroom practices in order to offer an indepth explanation of the relationship between beliefs and practices of teachers. This study can also be complimented with students' beliefs of grammar teaching, which we hope to accomplish in future studies.

\section{REFERENCES}

[1] Alderson, J. C. and D. Wall. (1993). 'Does washback exist?' Applied Linguistics, 14: 116 - 29.

[2] Altunbasak, İ. (2010). Turkish English teachers' beliefs about grammar teaching and their grammar teaching practices. Unpublished master's thesis.

[3] Andrews, S. (2007). Teacher language awareness. Cambridge: Cambridge University Press.

[4] Atkinson, D. (1987). The mother tongue in the classroom: A neglected source? ELT Journal, 41 (4), 241 - 247.

[5] Baleghizadeh, S., \& Farshchi, S. (2009). An exploration of teachers' beliefs about the role of grammar in Iranian high schools and private language institutes. Journal of English Language Teaching and Learning, 52 (212), 17-38.

[6] Basturkmen, H., Loewen, S., Ellis, R. (2004). Teachers' stated beliefs about incidental focus on form and their classroom practices. Applied Linguistics 25, 243-272.

[7] Borg, S. (1999). Studying teacher cognition in second language grammar teaching. System, 27(1), 19-31.

[8] Borg, S. (2001). Self-perception and practice in teaching grammar. ELT Journal. 55(1), 21-29.

[9] Borg, S. (2003). Teacher cognition in language teaching: a review of research on what language teachers think, believe, know and do. Language Teaching, 36, 81-39.

[10] Borg, S. (2006). The distinctive characteristics of foreign language teachers. Language Teaching Research, 10(1), 3-31.

[11] Borg, S., \& Burns, A. (2008). Integrating grammar in adult TESOL classrooms. Applied Linguistics, 29(3), 456-482.

[12] Burgess, J., \& Etherington, S. (2002). Focus on grammatical form: Explicit or implicit? System, 30, 433-458.

[13] Burns, A. (1996). Starting all over again: From teaching adults to teaching beginners. In D. Freeman, \& J. C. Richards (Eds), Teacher learning in language teaching (pp. 154-177). Cambridge, UK: Cambridge University Press.

[14] Calderhead, J. (1996). Teachers: Beliefs and knowledge. In D. Berliner \& R. Calfee (Eds.), Handbook of educational psychology (pp. 709-725). New York: Macmillan.

[15] Canagarajah, A. S. (2005). Reclaiming the local in language policy and practice. Mahwah, NJ: Lawrence Erlbaum.

[16] Chia, S.C.C. (2003). Singapore primary teachers' beliefs in grammar teaching and learning. Deterding, A.S. Brown \& E.L. Low (Eds.), English in Singapore: Research on grammar (pp. 117-127). Singapore: McGraw-Hill.

[17] Clark, C. M., \& Peterson, P. L. (1986). Teachers' thought processes. In M. C. Wittrock (Ed.), Handbook of research on teaching (3rd ed., pp. 255-296). New York: Macmillan.

[18] Creswell, J. W. (2009). Research design: Qualitative, quantitative, and mixed methods approaches (3rd ed.). Thousand Oaks, CA: Sage Publications.

[19] Dörnyei, Z. (2007). Research Methods in Applied Linguistics. OUP, Oxford.

[20] Eisenstein Ebsworth, M. \& Schweers, C. (1997). What researchers say and practitioners do: Perspectives on conscious grammar instruction in the ESL classroom. Applied Language Learning, 8(2), 205-228.

[21] Ellis, R. (2006). Current issues in the teaching of grammar: An SLA perspective. TESOL Quarterly 40 (1), 83-108.

[22] Fang, Z. (1996). A review of research on teacher beliefs and practices. Educational Research, 38(1), 47-65.

[23] Farrell. T. S. C., \& Lim P.C.P. (2005). Conceptions of grammar teaching: A case study of teachers' beliefs and classroom practices. TESL-EJ 9, 1-13.

[24] Fenstermacher, G. D. (1979). A philosophic consideration of recent research on teacher effectiveness. In L. S. Shulman (Ed.), Review of Research in Education. 16, 157-185.

[25] Freeman, D. (2002). The hidden side of the work: teacher knowledge and learning to teach. Language Teaching, 35, 1-13.

[26] Gardner, R.C. and Lambert, W.E. (1982). The Role of the Integrative Motive on Students' Participation in the French Classroom. Canadian Modern Language Review, 38, 625-647.

[27] Johnson, K. E. (1994). The emerging beliefs and instructional practices of preservice English as a second language teachers. Teaching \& Teacher Education, 10(4), 439-452.

[28] Joyce, D. S. H., \& Burns, A. (1999). Focus on grammar. Sydney, NSW: National Centre for English Language Teaching and Research.

[29] Kagan, D. M. (1992). Implications of research on teacher belief. Educational Psychologist, 27(1), 65-90.

[30] Karavas-Doukas, E. (1995). Teacher identified factors affecting the implementation of an EFL innovation in Greek public secondary schools. Language, Culture and Curriculum, 8(1), 53-68. 
[31] Krashen, S. D. (1982). Principles and practice in second language acquisition (1st ed.). Oxford; New York: Pergamon.

[32] Long, M.H. (1991). Focus on form: A design feature in language teaching methodology. In K. de Bot, R. Ginsberg, \& C. Kramsch (Eds.), Foreign language research in cross-cultural perspective (pp.39-52). Amsterdam: John Benjamins.

[33] Long, H., \& Robinson, P. (1998). Focus on form: Theory, research and practice. In C. Doughty, \& J. Williams (Eds.), Focus on form in classroom second language acquisition (pp. 15-41). Cambridge, England: Cambridge University Press.

[34] Mohammed, N. (2006). An Exploratory Study of the Interplay between the Teachers' Beliefs, Instructional Practices, and Professional Development. Unpublished Doctoral Dissertation.

[35] Moini, M.R. (2009).The impact of EFL teachers" cognition on teaching foreign language grammar. Pazhuhesh-e Zabanha-ye Khareji, 49, 141-164.

[36] Nagata, N. (1997). An experimental comparison of deductive and inductive feedback generated by a simple parser. System, 25 (4), 515-534.

[37] National Institute of Education. (1975). Teaching as clinical information processing. (No. Panel 6, National Conference on Studies in Teaching.): National Institute of Education.

[38] Nishimuro, M., \& Borg, S. (2013). Teacher cognition and grammar teaching in a Japanese high school. JALT Journal, 35(1), 29-50.

[39] Nunan, D. 1989. Understanding Language Class- rooms. Hemel Hempstead: Prentice Hall.

[40] Pahissa, I., \& Tragant, E. (2009). Grammar and the non-native secondary school teacher in Catalonia. Language Awareness, 18(1), 47-60.

[41] Pajares, M. F. (1992). Teachers' beliefs and educational research. Review of Educational Research, 62(3), 307 - 332.

[42] Phipps, S., \& Borg, S. (2009). Exploring tensions between teachers' grammar teaching beliefs and practices. System, 37(3), 380-390.

[43] Richards, J.C. (1994). The sources of language teachers' instructional decisions. In Alatis, J.E. (ed.) Georgetown University Round Table on Languages and Linguistics. (pp.384-402). Washington, D.C.: Georgetown University Press.

[44] Richards, J. C., \& Lockhart, C. (1994). Reflective teaching in second language classrooms: Cambridge: Cambridge University Press.

[45] Richards, J. C., Gallo, P. B., \& Renandya, W. A. (2001). Exploring teachers' beliefs and the processes of change. The PAC Journal, 1(1), 41-62.

[46] Russell, J. \& Spada, N. (2006). The effectiveness of corrective feedback for the acquisition of L2 grammar: A meta-analysis of the research. In J.M. Norris \& L. Ortega (Eds.), Synthesizing research on language learning and teaching (pp. 133-64). Amsterdam: Benjamins.

[47] Rutherford, W.E. (1987). Second Language Grammar: Learning and Teaching. Harlow: Longman.

[48] Schulz, R. A. (2001). Cultural differences in student and teacher perceptions concerning the role of grammar instruction and corrective feedback: USA- Colombia. The Modern Language Journal, 85(2), 244-258.

[49] Schweers, W. Jr. (1999). Using L1 in the L2 classroom. English Teaching Forum, 37 (2), 6- 7.

[50] Tang, J. (2002). Using L1 in the English classroom. English Teaching Forum, 40 (1). 36-43

[51] Taylor, L. (2005). Washback and impact, ELT Journal, 59(2), 54-155.

[52] Williams, M., \& Burden, R. L. (1997). Psychology for language teachers: a social constructivist approach. Cambridge: Cambridge University Press.

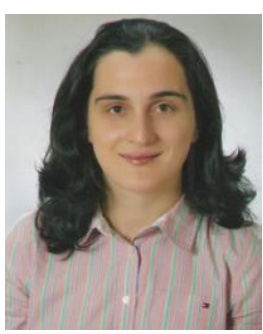

Rabia Hos is currently an assistant professor of language education at the Faculty of Education Zirve University, Turkey. She has taught English to Speakers of Other Languages (ESOL) and has worked as an administrator for ten years in the U.S. public schools. She has also worked as a visiting professor at the Warner Graduate School of Education at University of Rochester, NY. She has earned her Ph.D at the University of Rochester. Her research interests include critical pedagogy, social and cultural capital, refugee students with limited or interrupted formal education (SLIFE), curriculum development in language education, and professional development of language educators.

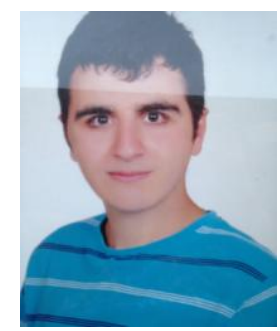

Mustafa Kekec is a senior student in the undergraduate English Language Teaching (ELT) department at the faculty of education at Zirve University. He is one of the few students who is majoring in both ELT and Psychological Counseling and Guidance. He aims to enter the academia when he graduates with both degrees in May 2014. His interests are psychological issues in language teaching, critical pedagogy, and language skills. 